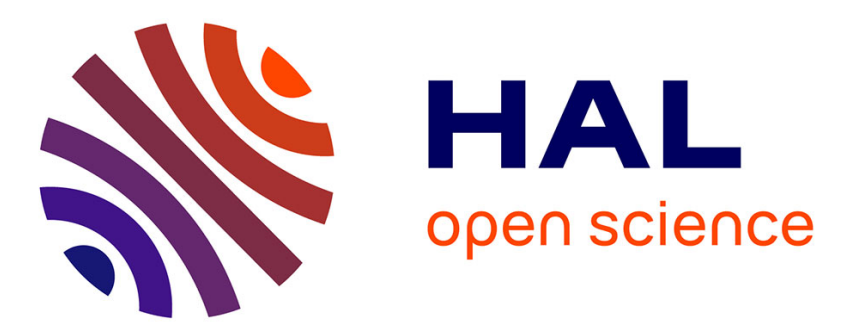

\title{
The LEI/L-DNase II pathway is activated in light-induced retinal degeneration in rats.
}

Sabine Chahory, Laura Padron, Yves Courtois, Alicia Torriglia

\section{To cite this version:}

Sabine Chahory, Laura Padron, Yves Courtois, Alicia Torriglia. The LEI/L-DNase II pathway is activated in light-induced retinal degeneration in rats.. Neuroscience Letters, 2004, 367 (2), pp.205-9. 10.1016/j.neulet.2004.06.004 . inserm-00143906

\section{HAL Id: inserm-00143906 https://www.hal.inserm.fr/inserm-00143906}

Submitted on 2 May 2007

HAL is a multi-disciplinary open access archive for the deposit and dissemination of scientific research documents, whether they are published or not. The documents may come from teaching and research institutions in France or abroad, or from public or private research centers.
L'archive ouverte pluridisciplinaire HAL, est destinée au dépôt et à la diffusion de documents scientifiques de niveau recherche, publiés ou non, émanant des établissements d'enseignement et de recherche français ou étrangers, des laboratoires publics ou privés. 
The LEI/L-DNase II pathway is activated in light-induced retinal degeneration.

Sabine Chahory*, Laura Padron*, Yves Courtois, Alicia Torriglia

${ }^{*}$ These authors contributed equally to this work.

INSERM U598, 15 rue de l'Ecole de Médecine, 75006 Paris, France

Corresponding author: Alicia Torriglia,

e-mail torrigli@infobiogen.fr

Tel: 33140467850

Fax: 33140467855 


\begin{abstract}
Purpose: Retinal death induced by light seems to be a caspase independent process. In this work we investigate the LEI/L-DNase II pathway, a caspase-independent pathway, in light-induced retinal degeneration in Fischer rats.

Methods: Measurement of DNase activity in total retinal extracts of light exposed Fischer rats was performed by analysing a plasmid degradation on an agarose gel. The same method was used to measure the in vitro activity of recombinant LEI (reticulocyte lysate) after incubation with calpains.

Results: L-DNase II activity is observed in retinal extracts of light exposed Fischer rats and increases with time illumination. In this apoptotic death, the activation of calpains has been shown. Here we show that L-DNase II activation is not catalized by calpains.
\end{abstract}

Conclusion: The present study indicates that the LEI/L-DNase II may be a possible pathway activated during photoreceptor apoptosis in light-induced retinal degeneration but that this pathway is not directly activated by calpains.

Key words: retina, light, retinal degeneration, apoptosis, serpin, endonuclease, L-DNase II, calpain, caspase independent, serine proteases. 


\section{Introduction}

Retinal degenerations, mainly represented by Retinitis Pigmentosa in man, are a common cause of blindness in Western countries. Light-induced retinal degeneration represents an animal model for the study of these diseases. Despite various origins of retinal degeneration (genetic or oxydative), it is well recognised that light exposure enhances retinal damage. Apoptosis is recognised as the final pathway of photoreceptor cell death in these diseases [1]. This form of cell death is a process of cellular autodestruction, involving characteristic morphological changes: plasma membrane blebbing, cell body shrinkage, formation of membrane-bound apoptotic bodies, which are engulfed by neighboring healthy cells [2]. Although the biochemical hallmarks of apoptosis are now well established, the molecular events that lead to photoreceptor apoptosis in light induced retinal degeneration remain poorly elucidated. The caspase family of cysteine proteases has been first described as the major regulators of apoptosis [2]. However it is becoming increasingly clear that apoptosis can occur without caspase activation [3]. According to recent studies, light-induced retinal apoptosis in rodents is a caspase-independent process that activates calpains $[4,5]$.

Different caspase-independent pathways have been described $[3,6]$. Several proteases have been involved in caspase-independent apoptosis: calpains, cysteine cathepsins $B$ and $L$, aspartate cathepsins $D$ and various serine proteases (Granzymes A and B, Omi/HtrA2, AP24) [3, 6]. The LEI (Leucocyte Elastase Inhibitor) / L-DNase II is one of these caspase independent pathways [7]. LEI belongs to the serpin (Serine 
Protease Inhibitor) superfamily and, as many members of this family, it displays a serine protease inhibitory activity. When apoptosis is induced under specific conditions (long term culture [8], decrease of intracellular pH [9]), LEl is transformed into L-DNase II, a molecule bearing an acid endonuclease activity [7]. This posttranslational modification is associated with a shift in the molecular weight of LEI (from $42 \mathrm{kDa}$ for the native form to $35 \mathrm{kDa}$ for the cleaved form and $27 \mathrm{kDa}$ for the full mature DNase). The LEI/ L-DNase II pathway has been recently characterised as a caspase-independent pathway that depends on the activation of serine proteases $[7,8]$.

In the present study, we investigate the involvement of the LEl/ L-DNase II in light-induced retinal degeneration in the rat and we show its activation. We also investigate whether calpains, recently implicated in this model [4], are able to directly transform LEI into L-DNase II. 


\section{Materials and methods}

Retinal light damage in rats

Eight to twelve week-old IOPS Fischer male rats born in our laboratory were exposed to a constant light for 1,2 and 5 days, at an illumination level of 90 foot candles provided by two $20 \mathrm{~W}$ white fluorescent bulbs suspended $20 \mathrm{~cm}$ above the bottom of transparent polycarbonate cages [10]. The rats were killed using carbon dioxide. Enucleation of the eyes was carried out immediately after killing. Neuroretina was dissected and frozen immediately at $-20^{\circ} \mathrm{C}$.

The evolution of retinal degeneration was followed by DAPI staining of the nuclear layers: the eyes were mounted in Tissue Tek OCT and stored at $-80^{\circ} \mathrm{C}$ until use. Serial sections $(10 \mu \mathrm{m})$ were prepared using a Bright OTF/AS cryostat, collected on gelatin coated slides and stored at $-20^{\circ} \mathrm{C}$. After remouval of OCT from the sections, they were permebialized with $0,3 \%$ Triton X100 in PBS for 10 min and then stained with DAPI.

Measurement of DNase activity of total retinal extracts.

After defrosting, the retina were homogenised in $10 \%$ weight-volume of $10 \mathrm{mM}$ Hepes, $\mathrm{pH} 7,4$, containing $50 \mathrm{mM} \mathrm{NaCl}$, using a Potter homogenizer. The homogenate was then incubated on ice for 15 minutes and centrifugated $\left(20000 \mathrm{~g}, 4^{\circ} \mathrm{C}\right)$ for 15 minutes. The protein concentration was evaluated with the BCA method (Pierce).

DNase activity of $15 \mu \mathrm{g}$ of retina was measured in $25 \mu$ of $20 \mathrm{mM}$ Tris-EDTA, pH 5,5, in the presence or in the absence of anti-L-DNase II at a $1 / 5$ dilution. The reaction, started with $1,5 \mu \mathrm{g}$ of a plasmid was allowed to proceed for different times at $37^{\circ} \mathrm{C}$ and was then stopped by incubation on ice. Plasmid DNA was then precipitated with 2 volumes of phenol-chloroform. After centrifugation $\left(15000 \mathrm{~g}, 4^{\circ} \mathrm{C}\right)$ for 15 minutes, the DNA was solubilized in $10 \mu \mathrm{l}$ of $\mathrm{H}_{2} \mathrm{O}$ and analysed using a $1 \%$ agarose gel. 


\section{LEI-Calpains interaction}

Recombinant LEI was produced by in vitro transcription-traduction using the rabbit reticulocyte lysate as indicated by the manufacturer (Promega) in the presence of ${ }^{35}$ S-methionine. $2 \mu$ l of recombinant LEI was diluted in $18 \mu \mathrm{PBS}(\mathrm{pH} 7,4)$ and incubated at $37^{\circ} \mathrm{C}$ overnight with three different enzymes : elastase $(0,5 \mathrm{mg} / \mathrm{ml})$, calpain I ( $1 \mathrm{mg} / \mathrm{ml})$ and calpain II $(1 \mathrm{mg} / \mathrm{ml})$. Calpains were diluted in a buffer containing $100 \mathrm{mM}$ imidazole, $1 \mathrm{mM} \beta$-mercapto-ethanol, $5 \mathrm{mM}$ L-cystein, 4 \% DMSO, $10 \mathrm{mM}$ $\mathrm{CaCl}_{2}, \mathrm{pH} 7,3$ [4]. After different times of incubation, the samples were precipitated in $10 \%$ trichloracetic acid, incubated on ice for 2 hours, centrifugated $\left(15000 \mathrm{~g}, 4^{\circ} \mathrm{C}\right)$ for 15 minutes and then solubilized with Laemmli sample buffer. The samples were loaded on a $12 \%$ acrylamide discontinuous gel. After the run, gels were incubated in $30 \%$ methanol and $10 \%$ acetic acid for one hour and then incubated in a scintillant solution (En ${ }^{3}$ hance, NEN science product) for 30 minutes. They were then washed in $\mathrm{H}_{2} \mathrm{O}$ for 30 minutes, deshydrated for 5 minutes, dried and exposed to a Kodak X-OMAT S autoradiographic film.

Measurement of DNase activity of LEI incubated with calpains.

An equimolar quantity of recombinant LEI was incubated with calpains or elastase at room temperature for one night. Calpains were diluted in $100 \mathrm{mM}$ Imidazole, $1 \mathrm{mM}$ $\beta$-mercaptoethanol, $5 \mathrm{mM} \mathrm{L-cysteine,} \mathrm{4 \%} \mathrm{DMSO,} 10 \mathrm{mM} \mathrm{CaCl}_{2}, \mathrm{pH}$ 7,3. Elastase was diluted in $50 \mathrm{mM}$ Hepes, $50 \mathrm{mM} \mathrm{NaCl}, 5 \%$ glycerol $0.1 \%$ Chaps, 10mM dithiothreitol, $\mathrm{pH}$ 7.2. After incubation, each preparation was diluted in $20 \mathrm{mM}$ Tris-EDTA buffer, $\mathrm{pH}$ 5,5 and concentrated by microfiltration on a Microcon Device (Millipore). Then, the DNase reaction was started with $1,5 \mu \mathrm{g}$ of plasmid for 30 minutes at $37^{\circ} \mathrm{C}$ and stopped by incubation on ice. The DNA was analysed on a $1 \%$ agarose gel. 


\section{Results and Discussion}

Apoptosis is the main pathway of photoreceptor death in retinal degeneration [1]. While caspase activation has been described in several models of photoreceptor apoptosis $[11,12,13]$, recent studies on light induced retinal degeneration show no activation of this pathway in this model $[4,5]$. The LEI/L-DNase II pathway, characterised in our laboratory ,is a caspase-independent pathway, that is activated by serine proteases [14,9]. Under specific conditions (acidic intracellular pH [9], treatment by elastase, oxidative stress [15]), LEI, a cytoplasmic protein with an anti-protease activity, is activated into L-DNase II, a nuclear protein that induces nuclear degradation. This pathway has been described in two models of apoptosis in retina: in developing chicken neural retina [16] and in ethanol induced cell death in ARPE-19 [15]. Studies on different models of apoptosis show that the cleavage of LEl into L-DNase II is not dependent of the tissue or cell line but mostly of the apoptotic stimulus. LEI/L-DNase II pathway may be an alternative process in oxidative stress [15].

In the present study, we investigate if L-DNase II is activated in light-induced retinal degeneration. Eight to twelve weeks old Fischer rats were maintained in constant white illumination from one to five days. The degree of light-induced retinal degeneration was quantified by measuring outer nuclear layer (ONL) thickness, which serves as an index of photoreceptor cell loss [10]. A decrease in ONL thickness is seen after 2 days of illumination and is maximal at 5 days, as seen in figure 1 . In order to investigate if L-DNase II activity is activated during light overexposure, we incubated total retinal extracts from rats at different exposure times with a supercoiled plasmid at $\mathrm{pH} 5,5$. As previously shown [17] under these conditions only acid DNases can be measured. Four stages were studied: without illumination, and after one, two and five days of illumination. Plasmidic DNA degradation was analyzed on a $1 \%$ agarose gel. 
Representative results of these experiments are shown in figure 2. The acid DNase activity increases with the time of illumination. At 2 days of illumination, DNA degradation is observed after 150 minutes of incubation while at 5 days of illumination, it occurs after 60 minutes of incubation. The maximal activity is observed at the stage 5 days of illumination. To verify if the DNase activity identified in our retinal extracts correspond to L-DNase II and not to other acid DNases that may exist in the extracts, same experiments were performed using a specific antibody directed against L-DNase II. This antibody was prepared and fully characterized in our laboratory [17]. Representative results of these experiments are shown in figure 2. When incubated with the L-DNase II antibody, DNA degradation is inhibited. These experiments indicate that even if other nucleases bearing DNase II activity may exist or if DNA could be degraded by the acidic conditions used, L-DNase II seems responsible for most of DNA degradation in these retinal extracts.

The mechanism that leads to the activation of L-DNase II involves LEI cleavage by specific enzymes. Previous studies have shown that elastase-like molecules activate this enzyme under certain conditions [6]. In the retina, recent works have indicated that elastase is not required for L-DNase II activation during apoptosis in developing neural retina in the chick, where an acid protease seems to be responsible for LEI cleavage [18]. Moreover, we have recently shown that AP24 can also activate L-DNase II, indicating that several proteases might be involved in this same process [9]. Former studies showed that in light induced retinal degeneration, calpains instead of caspases are activated [4]. To investigate if calpains were able to transform LEI into L-DNase II, we synthetized recombinant LEI by in vitro transcription-traduction reaction and we incubated this preparation with both micro and macro calpains. Control experiments were done with elastase which is a specific substrat of LEI. 
Representative results of these experiments are shown in figure 3. After one hour of incubation, elastase forms a complex with LEI $(60 \mathrm{kDa})$. With longer incubation times, this complex is cleaved into a $35 \mathrm{kDa}$ band, as seen in the figure. As previously shown, this indicates that LEI has been transformed into L-DNase II. It is worth noting that proteases transforming LEI into L-DNase II do not degrade this protein further. So, a protease is qualified "activator of L-DNase II" when it has no proteolytic activity on L-DNase II. The incubation of LEI with calpains during the same periods, using an appropriate buffer for calpain activity, produced no complex or $35 \mathrm{kDa}$ form of LEl. These results show that the shift between LEI and L-DNase II is not due to the direct action of calpains. Moreover, calpains seem to degrade LEI since the amount of native LEI recovered after overnight incubation with calpains is reduced. This also indicate that calpains are active under our experimental conditions.

To confirm that calpains are not able to transform LEI into L-DNase II, even in a small amount, we measured the DNase activity of recombinant LEI after incubation with calpains. Control experiments were also done with elastase. Recombinant LEI was incubated with both micro and macro calpains, and with elastase overnight. Then each preparation was incubated at L-DNase II optimal buffer in the presence of a supercoiled plasmid. The DNase activity was analyzed on a 1\% agarose gel. Representative results are shown in figure 4. No DNase activity of LEl incubated with calpains was observed.

In the present study, the results indicate that calpains are not able to activate directly L-DNase II. As calpains are calcium-dependent proteases, investigations are underway to explore if calcium channel blockers may interfere with the activation of LEI and delay photoreceptor apoptosis in this model. Actually two hypothesis may explain the activation of L-DNase II shown in this paper and the activation of calpains shown by 
Donovan and al. [4]. Calpains may be activated in a second pathway at the same time than LEI/L-DNase II. Alternatively, calpains may belong to the same pathway than LEI but they might activate other proteolytic enzymes that mediate L-DNase II activation. Cathepsines for instance, might fulfil this function. They were shown to be activated by calpains in neural apoptosis during ischemia [19]. If the same occurs in light-induced retinal degeneration, cathepsins might then be responsible for L-DNase II activation. Further investigations are underway in our laboratory to decide between these hypothesis.

\section{Acknowledgments}

This work is supported by Retina France.

\section{References}

[1] Remé CE, Grimm C, Hafezi R, Marti A, WenzelA. Apoptotic cell death in retinal degenerations. Prog. Ret. Eye Res. 17 (1998): 443-464.

[2] Chang HY, Yang X. Proteases for Cell Suicide : functions and regulation of Caspases. Microbiol Mol Biol Rev 64 (2000) 821-846.

[3] Donovan M, Cotter TG. Control of mitochondrial integrity by Bcl-2 family members and caspase-independent cell death. Bioch Bioph Acta 1644 (2004) 133-47.

[4] Donovan M, Cotter TG. Caspase-independent photoreceptor apoptosis in vivo and differential expression of apoptotic protease activating factor- 1 and caspase- 3 during retinal development. Cell. Death Differ. 9 (2002): 1220-1231. 
[5] Doonan F, Donovan M, Cotter TG. Caspase-independent photoreceptor apoptosis in mouse models of retinal degeneration. J. Neurosci. 23 (2003) 5723-5731.

[6] Torriglia A, Perani P, Brossas JY, Altairac S, Zeggai S, Martin E, Tréton J, Courtois Y, Counis MF. A Caspase-Independent Cell Clearance Program. Ann. N Y Acad. Sci. 926 (2000) 192-203.

[7] Torriglia A. Molecular basis of the transformation of LEI into L-DNase II during apoptosis. Recent Res. Devel. Mol. Cell. Biol. 4 (2003): 23-38.

[8] Torriglia A, Negri C, Chaudun E, Prosperi E, Courtois Y, Counis MF, Scovassi AI. Differential involvement of DNases in HeLa cell apoptosis induced by etoposide and long term-culture. Cell Death Diff. 6: (1999) 234-244.

[9] Altairac S, Zeggai S, Perani P, Courtois $\mathrm{Y}$, Torriglia A. Apoptosis induced by $\mathrm{Na}(+) / H(+)$ antiport inhibition activates the LEI/L-DNase II pathway. Cell. Death Differ. 10 (2003) 548-557.

[10] Goureau O, Jeanny JC, Becquet F, Hartmann MP and Courtois Y. Protection against light-induced retinal degeneration by an inhibitor of NO synthase. Neuroreport 5 (1993) 233-236.

[11] Katai N, Kikuchi T, Shibuki H, Kuroiwa S, Arai J, Kurokawa T, Yoshimura N. Caspaselike proteases activated in apoptotic photoreceptors of Royal College Surgeon rats. Invest. Ophthalmol. Vis. Sci. 40 (1999) 1802-1807.

[12] Liu C, Li Y, Peng M, Laties AM, Wen R. Activation of caspase-3 in the retina of transgenic rats with the rhodopsin mutation s334ter during photoreceptor degeneration. J. Neurosci. 19 (1999) 4778-4785.

[13] Yoshizawa K, Yang J, Senzaki H, Uemura Y, Kiyozuka Y, Shikata N, Oishi Y, Miki $\mathrm{H}$, Tsubura A. Caspase-3 inhibitor rescues $\mathrm{N}$-methyl- $\mathrm{N}$-nitrosourea-induced retinal degeneration in Sprague-Dawley rats. Exp. Eye Res. 71 (2000) 629-635. 
[14] Belmokhtar CA, Torriglia A, Counis MF, Courtois $Y$, Jacquemin-Sablon A, Ségal-Bendirdjian S. Nuclear translocation of a Leucocyte Elastase Inhibitor/Elastase complex during Staurosporine-induced apoptosis: role in the generation of nuclear L-DNase II activity. Exp. Cell. Res. 254 (2000) 99-109.

[15] Brossas JY., Tanguy R., Brignole-Baudoin F., Courtois Y., Torriglia A., Tréton J.

L-DNase II associated with active process during ethanol induced cell death in ARPE-19. Mol Vis 10 (2004) 65-73

[16] Altairac S, Chaudun E, Courtois Y, Torriglia A. Elastase is not required for L-DNase II activation during apoptosis in developing chicken neural retina. Neurosci. Lett. 303 (2001) 41-44.

[17] Torriglia A, Chaudun E, Chany-Fournier F, Jeanny JC, Courtois Y, Counis MF. Involvement of DNase II in nuclear degeneration during lens cell differentiation, J. Biol. Chem.270 (1995) 28579-28585.

[18] Torriglia A, Chaudun E, Chany-Fournier F, Courtois Y, Counis MF. Involvment of L-DNase II in nuclear degeneration during chick retina development. Exp. Eye Res. 72 (2001) 443-453.

[19] Yamashima T. Implication of cysteine proteases calpain, cathepsin and caspase in ischemic neuronal death of primates. Prog. Neurobiol. 62 (2000) 273-295. 
Legends to figures:

Figure 1: sections from Fischer rats retinas non exposed (control) and exposed to constant illumination for 1,2 and 5 days were stained with DAPI. Compared to the control, a decrease in outer nuclear layer thickness is seen after 2 days of illumination and is maximal after 5 days. ONL: outer nuclear layer ; INL: inner nuclear layer; GCL: ganglion cell layer. Black bar repesents $60 \mu \mathrm{m}$.

Figure 2: DNase II activity in retinas of light exposed rats.

$15 \mu \mathrm{g}$ of total retinal extracts from rats non exposed and rats exposed to one, two and five days of illumination were incubated with a supercoiled plasmid in a DNase II activating buffer with and without anti-L-DNase II antibody. The cleavage of the plasmid in function of time was analyzed on a $1 \%$ agarose gel. The plasmid degradation increased with time of illumination and was maximal at five days of illumination. In the presence of anti-L-DNase II, plasmid degradation was completly inhibited indicating that L-Dnase II is responsible for this endonuclease activity.

Figure 3: Cleavage of LEI by calpains.

Recombinant LEI was incubated with elastase $(0,5 \mathrm{mg} / \mathrm{ml})$, calpain I $(1 \mathrm{mg} / \mathrm{ml})$ and calpain II $(1 \mathrm{mg} / \mathrm{ml})$ for one hour and overnight. After one hour of incubation with elastase, the intermediary complex between elastase and LEI is already seen. After an incubation of LEI with elastase overnight, the cleaved form of LEI ( $35 \mathrm{kDa}$ ) is present (arrow head). No band corresponding to this $35 \mathrm{kDa}$ form is present after incubation with calpains I and II but a decrease of the native form of LEI is seen

Figure 4: DNase II activity of LEl after calpains treatment. 
Recombinant LEI was incubated with elastase $(0,5 \mathrm{mg} / \mathrm{ml})$, calpain I $(1 \mathrm{mg} / \mathrm{ml})$ and calpain II $(1 \mathrm{mg} / \mathrm{ml})$ overnight. Each sample was then incubated with a supercoiled plasmid, as before. The cleavage of the plasmid in function of time was analyzed on a $1 \%$ agarose gel. The plasmid degradation was observed only after incubation with elastase. 